\title{
The role of tropical abandoned land relative to ecological and economic aspects
}

\author{
Karmini ${ }^{1^{*}}$, Karyati ${ }^{2 *}$, and Kusno Yuli Widiati ${ }^{2}$ \\ 1 Faculty of Agriculture, University of Mulawarman, Jl. Pasir Balengkong, Kampus Gunung Kelua, \\ Samarinda, East Kalimantan, Indonesia. 75119. Telp.: +62 541 749161, Fax.: +62 541 738341. e-mail: \\ karmini@faperta.unmul.ac.id \\ 2 Faculty of Forestry, University of Mulawarman, Jalan Ki Hajar Dewantara, Kampus Gunung Kelua, \\ Samarinda, East Kalimantan, Indonesia, 75119 Telp. +62 0541 735089, 749068 Fax. +62 541735379. \\ e-mail: karyati@fahutan.unmul.ac.id \\ * Correspondence author: karmini@faperta.unmul.ac.id; karyati@fahutan.unmul.ac.id
}

\begin{abstract}
The floristic structure and composition of abandoned lands in the tropic have been observed to be changing dynamically during the succession process. This is mostly because they are not utilized maximally, therefore, there is a need to assess the economic and ecological impacts of this land abandonment in tropical areas. This study was conducted to determine the ecological aspects of stand structure, floristic composition, and species diversity and analyze the economic aspects of standing trees in tropical abandoned land. The vegetation containing woody trees with a diameter at breast height (DBH) of $\geq 5 \mathrm{~cm}$ were surveyed at six subplots sized $20 \mathrm{~m} \times 20 \mathrm{~m}$. The economic parameters were evaluated using data of log price, logging cost, profit margin, and stumpage value of standing trees in the study plot and a total of 126 trees including 26 species of 25 genera of 18 families were recorded. The most common species found were Macaranga tanarius with $50.60 \%$, Bridelia glauca with $49.13 \%$, and Pterospermum javanicum with $29.05 \%$ based on Importance Value Index (IVi). Moreover, the diversity, dominance, evenness, and richness indices were 1.23, $0.09,0.87$, and 5.17 respectively while the total log price at the abandoned land was $1,462.02 \mathrm{USD} \mathrm{m}^{-3}$ with an average value of 56.23 USD $\mathrm{m}^{-3}$. The total and mean values of logging costs were 1,212.24 USD ha-1 and 46.62 USD ha-1, respectively while the total profit margin of log selling was USD337.39 $\mathrm{m}^{-3}$ at maximum with an average of $12.98 \mathrm{USD} \mathrm{m}^{-3}$. Furthermore, the average stumpage value was $83.05 \mathrm{USD} \mathrm{ha}^{-1} \mathrm{while}$ the total was calculated to be 2,159.36 USD ha-1. These findings showed the utilization of abandoned lands with respect to ecology and economic aspects has the ability to increase community welfare and support the implementation of developmental programs in the country.
\end{abstract}

Keywords: Abandoned land; diversity; economic; floristic structure; stumpage value

\section{Introduction}

The dynamics taking place at several scales determine plant diversity within regenerating fallows (Lawrence, 2004) exploited for agricultural purposes, mainly through shifting cultivation. This is observed to be a global phenomenon because two-thirds of the world's secondary forests were recorded to have been cultivated through the process in 1980 with $49 \%$ recorded annually in tropical Asia (Lanly, 1982). These forests are defined as the vegetation resulting from the clearing of natural high forest for shifting cultivation before abandonment (Abebrese, 2002; Johnson and Miyanishi, 2007; Keddy, 2007; Misra, 1992). They are characterized by the structure and extent of vegetative cover as well as their composition in terms of dominant and secondary species (Mittelman, 2001; Van Breugel et al., 2006). However, the principal types include the Swidden fallow secondary forests and some other gardens as reported by Chokkalingam et al. (2001).

According to Van Breugel et al. (2006), understanding the mechanisms of secondary forest succession requires the consideration of the time of abandonment as a compound factor to integrate the variables of plant community ecology - the total effective conditions determining the existence of the plants on the land (Tansley, 1993). Secondary forests are caused by human activity and fast-growing ecosystems whose species life cycles coincide with those of human land uses. In addition, they are also assets for the conservation of biodiversity in the tropics due to their many 
biotic characteristics such as the ability to improve soil and water quality as well as to conserve genetic material, nutrients, moisture, and/or soil organic matters (Brown and Lugo, 1990).

With the continuous depletion of primary forests, secondary forests have become increasingly important to maintain the larger habitat for biodiversity conservation (Mittelman, 2001). This is associated with their coverage of more than 600 million ha of the land area in the tropics which accounts for about $40 \%$ of the total forest area as well as the formation rates estimated at 9 million ha year ${ }^{-1}$ (Brown and Lugo, 1990). Moreover, FAO (1996) estimated the area of secondary forest in 1990 in Asia to be 87.5 million ha while the figures for Latin America and Africa were 165 and 90 million ha, respectively. These data and the awareness of the accelerated changes in the forest situations in countries like the Philippines, Indonesia, China, and Malaysia strongly suggest future goods and services obtained from tropical forests would increasingly be sourced from secondary or some other kinds of anthropogenically-induced forests such as the timber, environmental services, biodiversity conservation, and forest products for the rural poor (De Jong et al., 2001).

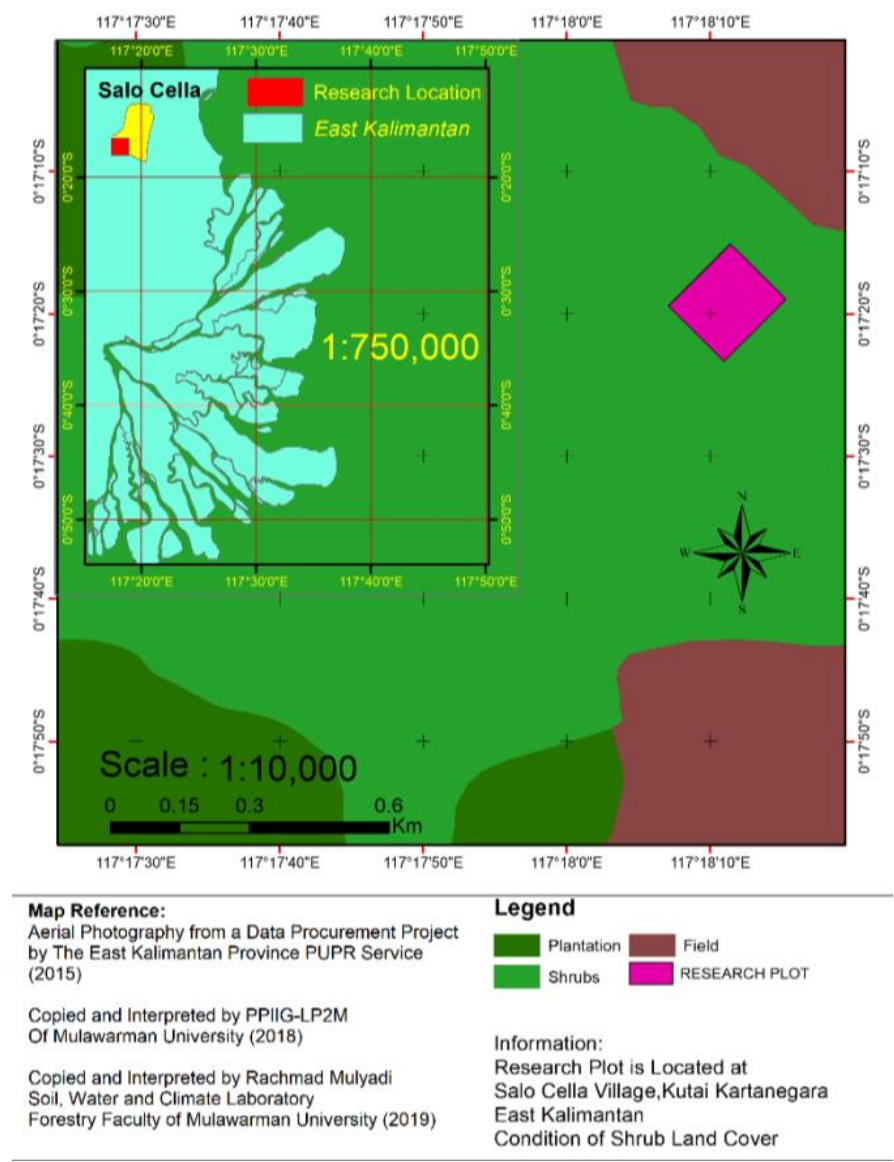

Figure 1. Map of the study site in Muara Badak Sub-district, Kutai Kartanegara District, East Kalimantan Province, Indonesia.

The total land area in Indonesia is estimated to be 190 million hectares and $2 / 3$ of these are referred to as forest areas managed by the Ministry of Forestry while the remaining $1 / 3$ is for business (HGU) and building (HGB). However, the National Land Agency (BPN) indicated 7.5 million hectares of land has the potential to be abandoned, both in and outside the forest areas, and several people have assumed these lands have no usefulness. However, they have certain ecological and economic benefits and several studies have been conducted on the ecological aspect such as the floristic composition and structure of the tropical secondary forest in Borneo Island as well as the 
less information provided on the ecological and economic aspects of tropical abandoned land in East Kalimantan. This study was, therefore, conducted to determine the ecological aspect such as stand structure, floristic composition, and species diversity as well as the economic aspect of standing trees such as log price, logging cost, profit margin, and stumpage value in an abandoned land. The findings are expected to be useful in conserving and managing tropical forest and environmental ecosystems.

\section{Materials and methods}

\subsection{Study site}

The study was conducted in Salo Cella Village, Muara Badak Sub-district, Kutai Kartanegara Districts, East Kalimantan Province, Indonesia with the geographic location of $0^{\circ} 17^{\prime} 18.7^{\prime \prime} \mathrm{S}$ $117^{\circ} 18^{\prime} 08.2^{\prime \prime} \mathrm{E}$ as shown in Figure 1. Salo Cella is one of 13 villages in Muara Badak located $10 \mathrm{~km}$ from the capital of Sub-district with a population of 49,361,000 most of which are farmers and an area of $939.09 \mathrm{~km}^{2}$ dominated by lowland mixed dipterocarp forest. Moreover, the average monthly and amount of rainfall were recorded to be $92 \mathrm{~mm}^{3}$ and 9 raindays in 2018 (Statistics Kutai Kartanegara Regency, 2019). The subdistrict is administratively bordered by Marang Kayu Subdistrict, Anggana Sub-district Samarinda City, Makassar Strait, and Tenggarong Seberang Sub-district on the north, south, east, and west respectively. Furthermore, the sectors of Muara Badak with economic potentials are oil and gas, fishery, and plantation.

\subsection{Data collection}

The vegetation and economic surveys of the study site were conducted from March to August 2019 through the establishment of six subplots sized $20 \mathrm{~m} \times 20 \mathrm{~m}$. Moreover, all woody trees with DBH of $\geq 5 \mathrm{~cm}$ within the plot were enumerated and their species identified.

\subsection{Data analysis}

\subsubsection{Ecological aspect}

Individual basal area (BA) and volume (V) were determined using the following formulas (Husch et al. 1982):

Individuals $\mathrm{BA}=\pi(\mathrm{DBH} / 2)^{2} \cdot 10^{-4}$

Individuals $\mathrm{V}=1 / 4 \pi \times \mathrm{DBH}^{2} .10^{-4} \times \mathrm{H} \times f$

where: DBH is the diameter at breast height $(\mathrm{cm}),{ }^{\prime} \mathrm{H}$ ' is tree height $(\mathrm{m})$, and ' $f$ ' is the form factor.

The dominant species within the plots were measured using the Importance Value Index (IVi) (Fachrul, 2007):

$\mathrm{RF}=($ Frequency of a species / Total frequencies of all species $) \times 100$

$\mathrm{Rd}=$ (The number of individual species / Total number of individuals) $\times 100$

$\mathrm{RD}=$ (Total basal area for a species $/$ Total basal area for all species $) \times 100$

$\mathrm{IVi}=\mathrm{RF}+\mathrm{Rd}+\mathrm{RD}$

where: $R F$ is relative frequency, $R d$ is relative density, and $R D$ is relative dominance.

The species diversity for standing trees in the study site was described using four indices including Shannon-Wiener's diversity index $\left(H^{\prime}\right)$, Simpson's dominance index $\left(D_{s}\right)$, Pielou's evenness index $\left(J^{\prime}\right)$, and Margalef's richness index $(R)$ (Odum 2005):

$$
H^{\prime}=-\sum_{i=1}^{s}\left(\frac{n_{i}}{N}\right) \ln \left(\frac{n_{i}}{N}\right)
$$




$$
\begin{aligned}
& D_{s}=\sum_{i=1}^{s}\left(\frac{n_{i}}{N}\right)^{2} \\
& J^{\prime}=\frac{H^{\prime}}{\ln (S)} \\
& R=\frac{(S-1)}{\ln n}
\end{aligned}
$$

where $n_{i}=$ number of individuals of the $i$ - th species, $N=$ total number of all the individuals in a unit area, and $S=$ number of species in each plot.

\subsubsection{Economic aspect}

The equivalent merchantable height, number of logs, and diameter class are presented in Table 1 while the reduction factors of log price based on the diameter class are shown in Table 2.

Table 1. Merchantable tree heights.

\begin{tabular}{ccc}
\hline Diameter class $\mathbf{( c m})$ & Number of logs $\mathbf{( 5} \mathbf{~}$ long) & Equivalent merchantable height $\mathbf{( m )}$ \\
\hline $15-30$ & 1 & 5 \\
$+30-60$ & 2 & 10 \\
$+60-75$ & 3 & 15 \\
75 ke atas & 4 & 20 \\
\hline
\end{tabular}

Source: Forestry Department of Pinansular Malaysia (FDPM) (1997)

Table 2. Reduction cost of log price.

\begin{tabular}{cc}
\hline DBH size class $(\mathbf{c m})$ & Reduction factor \\
\hline $15-29$ & 0,450 \\
$30-44$ & 0,300 \\
$45-49$ & 0,150 \\
$50-54$ & 0,025 \\
55 and above & 0,000 \\
\hline
\end{tabular}

Source: Noor et al. (1992) and Hanum et al. (2001)

Logging cost was reported to be $480,000.00$ IDR (Hikmat, 2005) while the profit ratio was $30 \%$ (Noor and Shahwahid, 1999). Therefore, the equation to calculate the profit margin (Noor and Shahwahid, 1999) is presented as follows:

$P M_{i j}=\sum_{i=1}^{n} \sum_{j=1}^{k}\left(P_{i j} x P R\right) /(1+P R)$

Where $P M_{i j}=$ profit margin, $P_{i j}=\log$ price for each species at sawmill and diameter class, $P R=$ profit ratio, $i=$ an index for each species $(i=1,2,3,4, \ldots ., n)$, and $j=$ an index for diameter class $(i=1,2$, $3,4, \ldots ., n)$.

Meanwhile, the stumpage values were calculated using the following equation:

$S_{i j}=\sum_{i=1}^{n} \sum_{j=1}^{k} V_{i j}\left(P_{i j}+C_{i j}+P M\right)$

Where $S_{i j}=$ stumpage value for each species and diameter class (USD ha $\left.{ }^{-1}\right), V_{i j}=$ volume of timber for each species and diameter class $\left(\mathrm{m}^{3}\right), P_{i j}=\log$ price for each species at sawmill and diameter class $\left(\right.$ USD $\left.~^{-3}\right), C_{i j}=$ average logging cost $\left(\right.$ USD ha $\left.{ }^{-1}\right), P M_{i j}=$ profit margin $\left(\right.$ USD m $\left.{ }^{-3}\right), i=$ an index for each species $(i=1,2,3,4, \ldots ., n)$, and $j=$ an index for diameter class $(i=1,2,3,4, \ldots ., n)$. The exchange 
rate was 1 USD equal with 13,666 IDR at 21 January 2020.

\section{Results and discussion}

\subsection{Ecological aspect}

\subsubsection{Diameter at Breast Height (DBH) and Height Distributions}

There was a difference in the density of trees in the DBH classes as observed with the formation of L-shape characterized by the reduction in the total number of trees as the DBH increased as illustrated in Figure 2. There were 88 trees with the DBH size of $5.0-15.0 \mathrm{~cm}$, followed by 22 trees $(17 \%)$ with the DBH size of $15.1-25.0 \mathrm{~cm}, 14$ trees $(11 \%)$ with the DBH size of $25.1-35.0 \mathrm{~cm}$, and 2 trees (2\%) with the DBH size of more $35 \mathrm{~cm}$. The abandoned land was also observed to be dominated by $70 \%$ of all trees having DBH $\geq 5 \mathrm{~cm}$ in the $5.0-15.0 \mathrm{~cm}$ class. Moreover, the tree diameter distribution formed a reverse-J-shape (Feldpausch et al., 2007; Álvarez-Yépiz et al., 2008) while the distribution of the classes of the height was skewed slightly positively (Ohtsuka, 1999) as shown in Figure 3 with approximately $58 \%$ of the trees included in the $5.1-10.0 \mathrm{~m}$ class. The overall composition was 18 trees (14\%) of 0-5.0 m height, 73 trees (58\%) of 5.1-10.0 m height, 19 trees (15\%) of 10.1-15.0 height, 7 trees (6\%) of 15.1-20.0 height, and 9 trees (7\%) of more than $20.0 \mathrm{~cm}$ height.

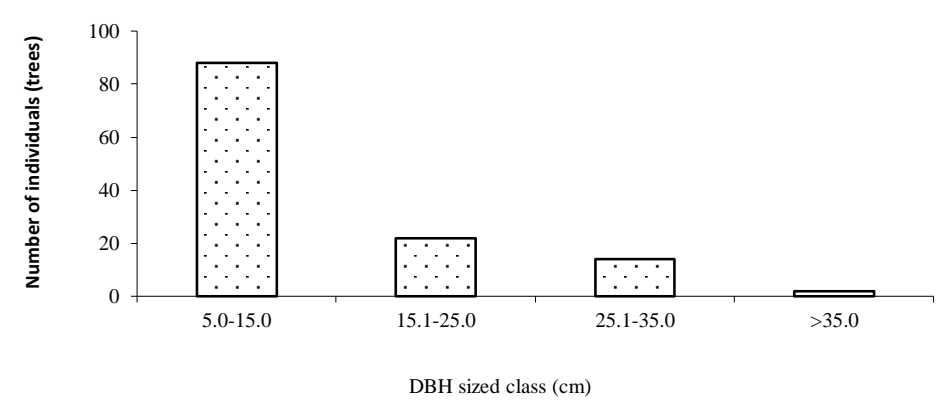

Figure 2. Distributions of diameter at breast height (DBH) in 0.24 ha of abandoned land.

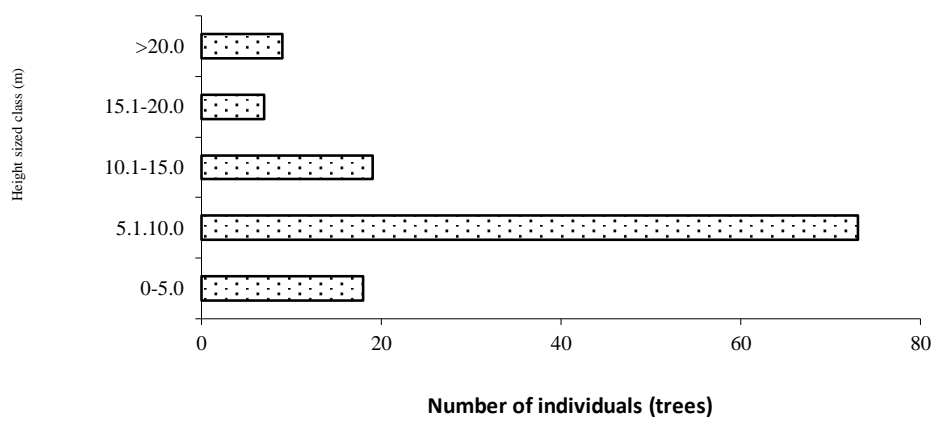

Figure 3. Distributions of height at different ages in 0.24 ha of abandoned land.

3.1.2 Density, basal area, and volume 
The density, basal area, and volume of species at a DBH of $>5 \mathrm{~cm}$ are presented in Table 3 . Twenty six species of 18 families were recorded in the study site. Three species such as Bridelia glauca, Glochidion obscurum, and Baccaurea sp. were included to Phyllanthaceae. Similarly, Macaranga tanarius, Homalanthus sp., and Macaranga gigantea were from Euphorbiaceae. The other 16 families had one species each. The density was found to be 126 trees in 0.24 hectare and the dominating species of trees based on the number of individuals include Macaranga tanarius with 38 , Bridelia sp. with 20 , Homalanthus sp. with 11 , Pterospermum javanicum with 8 , and Ficus septica with 5. The other species had number of individuals of $\leq 4$ trees. The average of DBH and height of trees were $14.3 \mathrm{~cm}$ and $10.5 \mathrm{~m}$, respectively. Regarding the basal area and volume per hectare, three dominant species were also observed and they include Bridelia glauca with $2.10 \mathrm{~m}^{2} \mathrm{ha}^{-1}$ and 23.24 $\mathrm{m}^{3}$ ha-1, Pterospermum javanicum with $1.64 \mathrm{~m}^{2}$ ha $^{-1}$ and $18.42 \mathrm{~m}^{3}$ ha-1 , and Ficus sp. with $1.24 \mathrm{~m}^{2}$ ha ${ }^{1}$ and $11.74 \mathrm{~m}^{3} \mathrm{ha}^{-1}$ for basal area and volume respectively. This, therefore, means these three species covered more than 58 percent of the total volume while other six species including Trema Orientalis, Trema Orientalis, Glochidion sp., Duabanga moluccana, Pometia pinnata, and Cananga odorata had more than $3.70 \mathrm{~m}^{3} \mathrm{ha}^{-1}$. The four species of Nephelium sp., Nauclea sp., Artocarpus elasticus, and Homalanthus sp. had relative high volume $\left(>1.07 \mathrm{~m}^{3} \mathrm{ha}^{-1}\right)$. While 13 other species had few basal area (0.02 to $\left.0.15 \mathrm{~m}^{2} \mathrm{ha}^{-1}\right)$ and volume (0.07 to $\left.0.83 \mathrm{~m}^{3} \mathrm{ha}^{-1}\right)$. Macaranga gigantea, Vitex pubescens, and Dillenia suffruticosa were three dominant species in terms of density, basal area and volume per hectare in the 5 and 10 year old after abandoned lands. In addition, Macaranga hypoleuca and Macaranga caladifolia were also common in the 10 year old of abandoned land, while Macaranga trichocarpa in the 5 year old of abandoned land (Karyati et al., 2018).

\subsubsection{Importance value index (IVi)}

The study site was dominated by light-demanding pioneer and fast-growing species in terms of IVi as presented in Table 4. However, the same four species observed to be predominant with total basal area and volume were also found for the IVi and they include Macaranga tanarius with $50.60 \%$, Bridelia glauca with $49.13 \%$, Pterospermum javanicum with $29.05 \%$, and Ficus septica with $22.56 \%$. The other three species discovered to be following the aforementioned were Homalanthus sp., Trema orientalis, and Glochidion sp. with $18.89,16.10$, and $11.53 \%$, respectively. Three species of Euphorbiaceae were dominant in terms of the IVi. These three species such as Macaranga tanarius, Homalanthus sp., and Macaranga gigantea reached more than $72 \%$. Similarly, Euphorbiaceae was include the ten most important family in the tropic as reported by Danquah et al. (2011) and Nizam et al. (2006). From 18 species recorded, there were 10 species with IVi of more than 5 . The other 9 species reached IVi between 2 to 5 . Furthermore, the seedling and saplings plants of Ficus aurata and Macaranga sp. were also common based on the Summed Dominance Ratio (SDR) in 3 and 5 years of fallow lands in Sarawak (Karyati et al., 2013). This is in line with the findings of Karyati et al. (2018) that trees species in lands abandoned for 5 and 10 years were dominated by Macaranga spp.

\subsubsection{Species Diversity}

The species diversity or heterogeneity $\left(H^{\prime}\right.$ value) of the plot studied was categorized as 'intermediate' (Odum, 2005) according to the results presented in Table 5 while a low ecological dominance $\left(D_{s}\right.$ value) was also observed which means there were few or almost no species dominating the site. The high species diversity indicates a highly complex community (Brower et al., 1990). This was also supported by the high value of $J$ ' indicating all the species are evenly distributed in the community. These values may, however, be due to the high number of trees and the number of species. The species richness can be measured most simply by counting the number of species in an area (Krebs, 2001). Generally, the increasing diversity $\left(H^{\prime}\right)$, evenness $\left(J^{\prime}\right)$, and richness $(R)$ caused a reduction in dominance $\left(D_{s}\right)$ in accordance with the findings of a previous study that tree diversity declined while dominance increased linearly along a disturbance gradient (Sapkota et al., 2010). The 
typical of most tropical lowland forests are no single tree species with high frequency and dominance (Kartawinata et al., 1981).

Table 3. Density, basal area, and volume of species (DBH of $>5 \mathrm{~cm}$ ) in the study site.

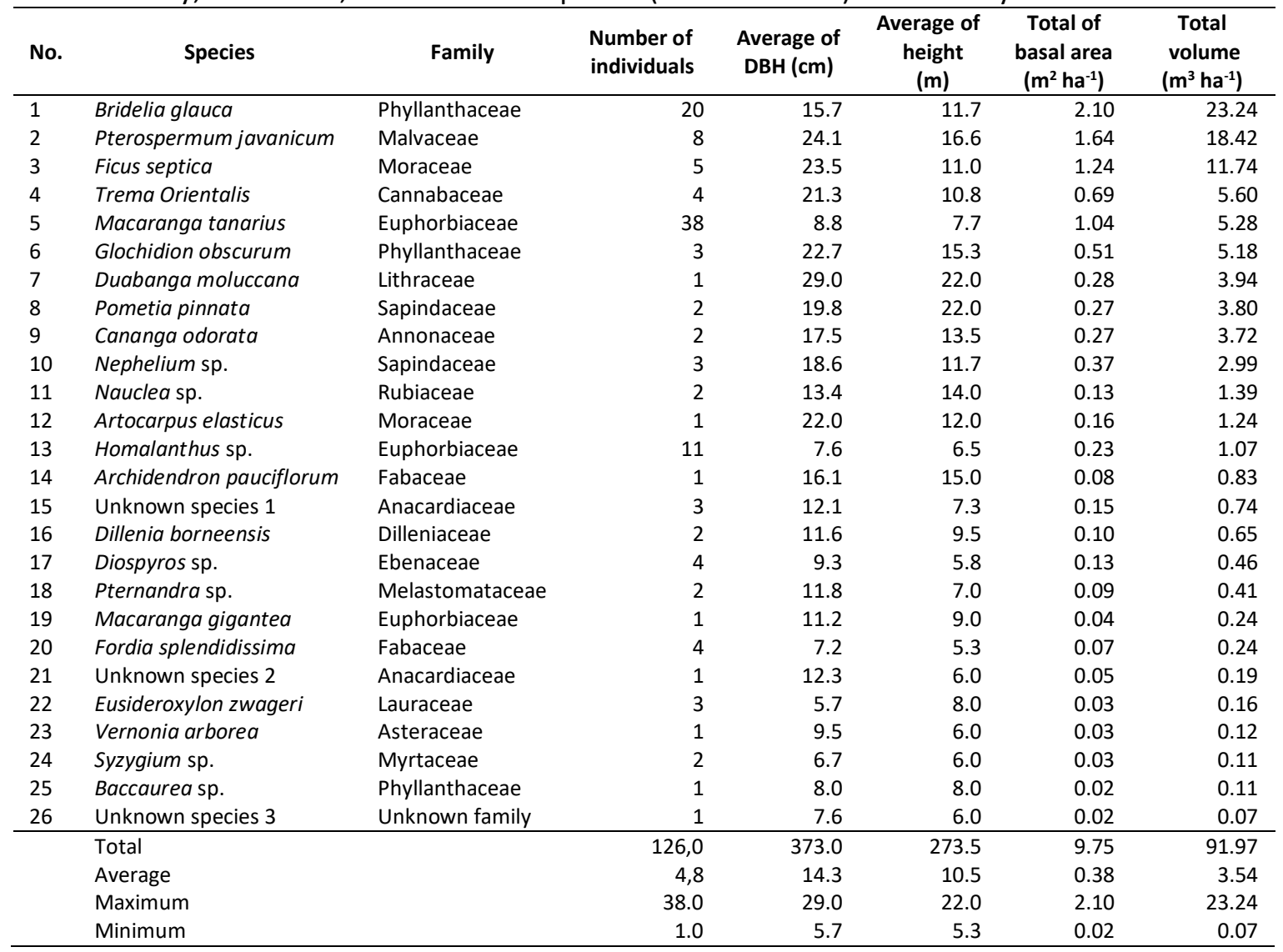

Note: $\mathrm{DBH}=$ diameter at breast height. The values were calculated based on vegetation surveyed in 0.24 hectare.

Table 4. Importance value index (IVi) of trees ( $\mathrm{DBH}$ of $>5 \mathrm{~cm}$ ) in 0.24 hectare of the study site.

\begin{tabular}{|c|c|c|c|c|c|c|}
\hline No. & Species & Family & RF (\%) & $\mathrm{Rd}(\%)$ & RD (\%) & IVi (\%) \\
\hline 1 & Macaranga tanarius & Euphorbiaceae & 9.80 & 30.16 & 10.64 & 50.60 \\
\hline 2 & Bridelia glauca & Phyllanthaceae & 11.76 & 15.87 & 21.50 & 49.13 \\
\hline 3 & $\begin{array}{l}\text { Pterospermum } \\
\text { javanicum }\end{array}$ & Malvaceae & 5.88 & 6.35 & 16.82 & 29.05 \\
\hline 4 & Ficus septica & Moraceae & 5.88 & 3.97 & 12.70 & 22.56 \\
\hline 5 & Homalanthus sp. & Euphorbiaceae & 7.84 & 8.73 & 2.32 & 18.89 \\
\hline 6 & Trema orientalis & Cannabaceae & 5.88 & 3.17 & 7.04 & 16.10 \\
\hline 7 & Glochidion obscurum & Phyllanthaceae & 3.92 & 2.38 & 5.23 & 11.53 \\
\hline 8 & Diospyros sp. & Ebenaceae & 3.92 & 3.17 & 1.35 & 8.45 \\
\hline 9 & Cananga odorata & Annonaceae & 3.92 & 1.59 & 2.80 & 8.30 \\
\hline 10 & Nephelium sp. & Sapindaceae & 1.96 & 2.38 & 3.82 & 8.17 \\
\hline 11 & Unknown species 1 & Anacardiaceae & 3.92 & 2.38 & 1.54 & 7.84 \\
\hline 12 & Nauclea sp. & Rubiaceae & 3.92 & 1.59 & 1.29 & 6.80 \\
\hline 13 & Eusideroxylon zwageri & Lauraceae & 3.92 & 2.38 & 0.34 & 6.64 \\
\hline 14 & Pometia pinnata & Sapindaceae & 1.96 & 1.59 & 2.72 & 6.27 \\
\hline 15 & Fordia splendidissima & Fabaceae & 1.96 & 3.17 & 0.71 & 5.85 \\
\hline 16 & Syzygium sp. & Myrtaceae & 3.92 & 1.59 & 0.30 & 5.81 \\
\hline 17 & Duabanga moluccana & Lithraceae & 1.96 & 0.79 & 2.82 & 5.58 \\
\hline
\end{tabular}




\begin{tabular}{|c|c|c|c|c|c|c|}
\hline No. & Species & Family & RF (\%) & Rd (\%) & RD (\%) & IVi (\%) \\
\hline 18 & Dillenia borneensis & Dilleniaceae & 1.96 & 1.59 & 0.99 & 4.54 \\
\hline 19 & Pternandra sp. & Melastomataceae & 1.96 & 1.59 & 0.93 & 4.48 \\
\hline 20 & Artocarpus elasticus & Moraceae & 1.96 & 0.79 & 1.62 & 4.38 \\
\hline 21 & $\begin{array}{l}\text { Archidendron } \\
\text { pauciflorum }\end{array}$ & Fabaceae & 1.96 & 0.79 & 0.87 & 3.62 \\
\hline 22 & Unknown species 2 & Anacardiaceae & 1.96 & 0.79 & 0.51 & 3.26 \\
\hline 23 & Macaranga gigantea & Euphorbiaceae & 1.96 & 0.79 & 0.42 & 3.18 \\
\hline 24 & Vernonia arborea & Asteraceae & 1.96 & 0.79 & 0.30 & 3.06 \\
\hline 25 & Baccaurea sp. & Phyllanthaceae & 1.96 & 0.79 & 0.21 & 2.97 \\
\hline \multirow[t]{2}{*}{26} & Unknown species 3 & Unknown family & 1.96 & 0.79 & 0.19 & 2.95 \\
\hline & Jumlah & & 100.00 & 100.00 & 100.00 & 300.00 \\
\hline
\end{tabular}

Note: $\mathrm{RF}=$ relative frequency, $\mathrm{Rd}=$ =relative density, $\mathrm{RD}=$ relative dominance; $\mathrm{IVi}=$ importance value index.

Table 5. Diversity indices of trees with $\mathrm{DBH}$ of $\geq 5 \mathrm{~cm}$ in the study site.

\begin{tabular}{clc}
\hline No. & \multicolumn{1}{c}{ Diversity indices } & Value \\
\hline 1 & Shannon-Wiener diversity index $\left(H^{\prime}\right)$ & 1.23 \\
2 & Simpson dominance index $\left(D_{s}\right)$ & 0.09 \\
3 & Pielou evenness index $\left(J^{\prime}\right)$ & 0.87 \\
4 & Margalef species richness $(R)$ & 5.17 \\
\hline
\end{tabular}

Note: The values were calculated according to the 6 subplots sized $20 \mathrm{~m} \times 20 \mathrm{~m}$ each.

The study showed the floristic structure, composition, and diversity were related to the existence and importance of the abandoned land dominated by fast-growing species. Moreover, the species of tree on the site had 'intermediate diversity' $\left(H^{\prime}\right)$, 'low dominance' $(D s)$, and 'high evenness' $\left(J^{\prime}\right)$ and the same was found for seedling-sapling plants with $\mathrm{DBH}<5 \mathrm{~cm}$ and tree plants with $\mathrm{DBH}>5 \mathrm{~cm}$ in 3, 5, 10, and 20 years after the lands have been fallowed (Karyati et al., 2013; Karyati et al., 2018). This, therefore, means abandoned land has important ecological roles. Furthermore, the information on the composition and diversity of plant regeneration at early stages of secondary succession on fallow lands is useful for biodiversity conservation and also provide social and economic values for future forest (Karyati et al., 2013). This shows it is necessary to understand the ecological and economic aspects of abandoned lands in order to manage and conserve them during successional periods in the tropic.

\subsection{Economic aspect}

\subsubsection{Log price}

The results showed the log prices for 10 species at the sawmill were different while Table 6 shows there were 525 stems ha-1 $^{-1}$ on the abandoned land. Moreover, the total and mean log price were 1,462.02 USD $\mathrm{m}^{-3}$ and 56.23 USD $\mathrm{m}^{-3}$, respectively with the highest values obtained at Eusideroxylon zwageri of Lauraceae with 526.85 USD m ${ }^{-3}$, Diospyros sp. of Ebenaceae with 263.43 USD $\mathrm{m}^{-3}$, Pometia zwageri of Sapindaceae with $125.13 \mathrm{USD} \mathrm{m}^{-3}$, and Artocarpus odoratissimus of Moraceae with 69.15 USD $\mathrm{m}^{-3}$. Furthermore, most of the other 22 species had the same value or were under 65.86 USD $\mathrm{m}^{-3}$. 
Table 6. Number of stems at abandoned land and log price.

\begin{tabular}{|c|c|c|c|c|}
\hline No. & Species & Family & $\begin{array}{c}\text { Number } \\
\text { (stems ha-1) }\end{array}$ & $P_{i j}\left(\right.$ USD m $\left.{ }^{-3}\right)$ \\
\hline 1 & Eusideroxylon zwageri & Lauraceae & 13 & 526.85 \\
\hline 2 & Diospyros sp. & Ebenaceae & 17 & 263.43 \\
\hline 3 & Pometia pinnata & Sapindaceae & 8 & 125.13 \\
\hline 4 & Artocarpus odoratissimus & Moraceae & 4 & 69.15 \\
\hline 5 & Archidendron pauciflorum & Fabaceae & 4 & 65.86 \\
\hline 6 & Nephelium sp. & Sapindaceae & 13 & 59.27 \\
\hline 7 & Pternandra sp. & Melastomataceae & 8 & 44.45 \\
\hline 8 & Dillenia borneensis & Dilleniaceae & 8 & 16.46 \\
\hline 9 & Macaranga tanarius & Euphorbiaceae & 158 & 16.46 \\
\hline 10 & Trema orientalis & Cannabaceae & 17 & 16.46 \\
\hline 11 & Syzygium sp. & Myrtaceae & 8 & 16.46 \\
\hline 12 & Homalanthus sp. & Euphorbiaceae & 46 & 16.46 \\
\hline 13 & Nauclea sp. & Rubiaceae & 8 & 16.46 \\
\hline 14 & Glochidion obscurum & Phyllanthaceae & 13 & 16.46 \\
\hline 15 & Fordia splendidissima & Fabaceae & 17 & 16.46 \\
\hline 16 & Vernonia arborea & Asteraceae & 4 & 16.46 \\
\hline 17 & Macaranga gigantea & Euphorbiaceae & 4 & 16.46 \\
\hline 18 & Cananga odorata & Annonaceae & 8 & 16.46 \\
\hline 19 & Duabanga moluccana & Lithraceae & 4 & 16.46 \\
\hline 20 & Baccaurea sp. & Phyllanthaceae & 4 & 16.46 \\
\hline 21 & Unknown species 1 & Anacardiaceae & 13 & 16.46 \\
\hline 22 & Unknown species 2 & Anacardiaceae & 4 & 16.46 \\
\hline 23 & Unknown species 3 & Unknown family & 4 & 16.46 \\
\hline 24 & Bridelia glauca & Phyllanthaceae & 83 & 16.19 \\
\hline 25 & Pterospermum javanicum & Malvaceae & 33 & 15.09 \\
\hline \multirow[t]{3}{*}{26} & Ficus septica & Moraceae & 21 & 13.17 \\
\hline & Total & & 525 & $1,462.02$ \\
\hline & Mean & & 20 & 56.23 \\
\hline
\end{tabular}

Note: $P_{i j}=\log$ price for each species at sawmill and diameter class.

The log price depends on the species and diameter class of log such that trees with high timber quality and many sales in the market have higher log prices. However, a bigger diameter at breast height (DBH) led to a lower reduction factor and higher log price. This means it is easier to produce different kinds of products from the logs with big DBH and timber volume. Moreover, high community demand for logs of particular species usually increases their prices in the market in accordance with the laws of demand.

Trees with high log prices are in a small number on the abandoned land with an average of 20 stems ha-1 for each species. The Eusideroxylon zwageri (Lauraceae) had only 13 stems ha $^{-1}$, Diospyros sp. (Ebenaceae) with 17 stems ha-1 while Pometia pinnata (Sapindaceae) and Artocarpus odoratissimus (Moraceae) had 8 stems ha-1 and 4 stems ha- ${ }^{-1}$, respectively. This is, however, in line with the law of supply which states that a smaller supply of the commodity to the market leads to a higher price.

A different result was, however, observed with other species such as Macaranga tanarius (Euphorbiaceae) with a total number of 158 stems ha- $^{-1}$ and a log price of 16.46 USD m$^{-3}$ and other families and species with low log prices. This means several factors determine the price of log in the market and they include tree diameter, timber quality, consumer taste, and others. According to Noor et al. (2007a), the market price is the first point of sale where the product is sold freely in the competitive market. 


\subsubsection{Logging cost}

Logging cost was the same for each species of trees and was found to be USD35.12 $\mathrm{m}^{-3}$ including the costs for the chainsaw man, machine used, fuel, and depreciation. Table 7 shows the total and mean logging costs in the abandoned land were 1,212.24 USD ha-1 and 46.62 USD ha-1 $^{-1}$ respectively with the lowest being 0.72 USD ha-1 for 4 stems from Anacardiaceae family while the highest was 277.17 USD ha ${ }^{-1}$ for 21 stems from Ficus septica (Moraceae).

Table 7. Logging cost of trees.

\begin{tabular}{|c|c|c|c|c|}
\hline No. & Species & Family & $\begin{array}{c}\text { Number } \\
\text { (stems ha-1) }\end{array}$ & $C_{i j}($ USD ha-1) \\
\hline 1 & Ficus septica & Moraceae & 21 & 277.17 \\
\hline 2 & Bridelia glauca & Phyllanthaceae & 83 & 264.77 \\
\hline 3 & Pterospermum javanicum & Malvaceae & 33 & 258.63 \\
\hline 4 & Trema orientalis & Cannabaceae & 17 & 77.30 \\
\hline 5 & Glochidion obscurum & Phyllanthaceae & 13 & 58.19 \\
\hline 6 & Macaranga tanarius & Euphorbiaceae & 158 & 49.69 \\
\hline 7 & Nephelium sp. & Sapindaceae & 13 & 39.72 \\
\hline 8 & Duabanga moluccana & Lithraceae & 4 & 31.42 \\
\hline 9 & Pometia pinnata & Sapindaceae & 8 & 30.31 \\
\hline 10 & Cananga odorata & Annonaceae & 8 & 29.90 \\
\hline 11 & Artocarpus odoratissimus & Moraceae & 4 & 18.08 \\
\hline 12 & Nauclea sp. & Rubiaceae & 8 & 11.99 \\
\hline 13 & Unknown species 1 & Anacardiaceae & 13 & 11.55 \\
\hline 14 & Diospyros sp. & Ebenaceae & 17 & 11.32 \\
\hline 15 & Archidendron pauciflorum & Fabaceae & 4 & 9.68 \\
\hline 16 & Dillenia borneensis & Dilleniaceae & 8 & 9.43 \\
\hline 17 & Homalanthus sp. & Euphorbiaceae & 46 & 8.61 \\
\hline 18 & Pternandra sp. & Melastomataceae & 8 & 3.46 \\
\hline 19 & Fordia splendidissima & Fabaceae & 17 & 2.64 \\
\hline 20 & Unknown species 2 & Anacardiaceae & 4 & 1.80 \\
\hline 21 & Macaranga gigantea & Euphorbiaceae & 4 & 1.57 \\
\hline 22 & Eusideroxylon zwageri & Lauraceae & 13 & 1.26 \\
\hline 23 & Vernonia arborea & Asteraceae & 4 & 1.13 \\
\hline 24 & Syzygium sp. & Myrtaceae & 8 & 1.12 \\
\hline 25 & Baccaurea sp. & Phyllanthaceae & 4 & 0.80 \\
\hline 26 & Unknown species 3 & Unknown family & 4 & 0.72 \\
\hline \multicolumn{3}{|c|}{ Total } & 525 & $1,212.24$ \\
\hline \multicolumn{3}{|c|}{ Mean } & 20 & 46.62 \\
\hline
\end{tabular}

Note: $C_{i j}=$ logging cost of the tree.

Logging cost is, however, not determined by the number of trees cut but by the volume such that a higher estimation of log volume leads to a higher logging cost. Moreover, trees with high diameters were discovered to have more volume and vice versa, and those with small diameters were also found to have needed shorter logging time. Germain et. al. (2019) found two statistically significant variables influencing unit logging costs and they include volume per area harvested and the owner/operator experience such that an increase in these factors is expected to lower the perunit logging costs, with experience variable having the least effect. 


\subsubsection{Profit margin}

The total profit margin of selling logs was found to be 337.39 USD $\mathrm{m}^{-3}$ with an average of USD12.98 $\mathrm{m}^{-3}$. The highest value of 121.58 USD $\mathrm{m}^{-3}$ was obtained from Eusideroxylon zwageri (Lauraceae) while the lowest was recorded to be 3.04 USD m$^{-3}$ for Ficus septica (Moraceae) as shown in Table 8.

The factors determining the profit margin include the log price of each species at the sawmill and the class diameter such that the opportunity of the seller to make profit increases with a higher price and the log diameter.

Table 8. Profit margin.

\begin{tabular}{|c|c|c|c|c|}
\hline No. & Species & Family & $P_{i j}\left(\right.$ USD m$~ m^{-3}$ ) & $P M_{i j}\left(\right.$ USD m $\left.{ }^{-3}\right)$ \\
\hline 1 & Eusideroxylon zwageri & Lauraceae & 526.85 & 121.58 \\
\hline 2 & Diospyros sp. & Ebenaceae & 263.43 & 60.79 \\
\hline 3 & Pometia pinnata & Sapindaceae & 125.13 & 28.88 \\
\hline 4 & Artocarpus odoratissimus & Moraceae & 69.15 & 15.96 \\
\hline 5 & Archidendron pauciflorum & Fabaceae & 65.86 & 15.20 \\
\hline 6 & Nephelium sp. & Sapindaceae & 59.27 & 13.68 \\
\hline 7 & Pternandra sp. & Melastomataceae & 44.45 & 10.26 \\
\hline 8 & Dillenia borneensis & Dilleniaceae & 16.46 & 3.80 \\
\hline 9 & Macaranga tanarius & Euphorbiaceae & 16.46 & 3.80 \\
\hline 10 & Bridelia glauca & Phyllanthaceae & 16.19 & 3.74 \\
\hline 11 & Trema orientalis & Cannabaceae & 16.46 & 3.80 \\
\hline 12 & Syzygium sp. & Myrtaceae & 16.46 & 3.80 \\
\hline 13 & Homalanthus sp. & Euphorbiaceae & 16.46 & 3.80 \\
\hline 14 & Nauclea sp. & Rubiaceae & 16.46 & 3.80 \\
\hline 15 & Glochidion obscurum & Phyllanthaceae & 16.46 & 3.80 \\
\hline 16 & Fordia splendidissima & Fabaceae & 16.46 & 3.80 \\
\hline 17 & Vernonia arborea & Asteraceae & 16.46 & 3.80 \\
\hline 18 & Macaranga gigantea & Euphorbiaceae & 16.46 & 3.80 \\
\hline 19 & Cananga odorata & Annonaceae & 16.46 & 3.80 \\
\hline 20 & Duabanga moluccana & Lithraceae & 16.46 & 3.80 \\
\hline 21 & Baccaurea sp. & Phyllanthaceae & 16.46 & 3.80 \\
\hline 22 & Unknown species 1 & Anacardiaceae & 16.46 & 3.80 \\
\hline 23 & Unknown species 2 & Anacardiaceae & 16.46 & 3.80 \\
\hline 24 & Unknown species 3 & Unknown family & 16.46 & 3.80 \\
\hline 25 & Pterospermum javanicum & Malvaceae & 15.09 & 3.48 \\
\hline 26 & Ficus septica & Moraceae & 13.17 & 3.04 \\
\hline \multicolumn{3}{|c|}{ Total } & $1,462.02$ & 337.39 \\
\hline \multicolumn{3}{|c|}{ Mean } & 56.23 & 12.98 \\
\hline
\end{tabular}

Note: $P_{i j}=\log$ price at sawmill and diameter class; $P M_{i j}=$ profit margin.

\subsubsection{Stumpage Value}

The stumpage value was determined by the timber volume, log diameter, log price at the sawmill, and profit margin for each species and the total valued obtained was 2,159.36 USD ha-1. However, Figure 4 shows eight species had economic values above the mean stumpage values on the abandoned land with the mean contribution found to be 83.05 USD ha ${ }^{-1}$ while 18 species of other trees had values under the mean stumpage values.

The studies conducted in other location found different stumpage economic values, for example, in Ayer Hitam Forest Reserve, Puchong, Selangor, it was estimated to be RM 34,278,980 for timber, RM 67,192 for medical plants, RM 773,090 for dependence of indigenous people, RM 
865,770 for potential recreation benefits, and RM 2.39 billion for conservation value based on Malaysian adult population (Noor et. al. 2007b). Even though the values obtained in this study are lesser than the ones in Noor et. al. (2007b), it, however, shows abandoned land has many trees with potential economic values.

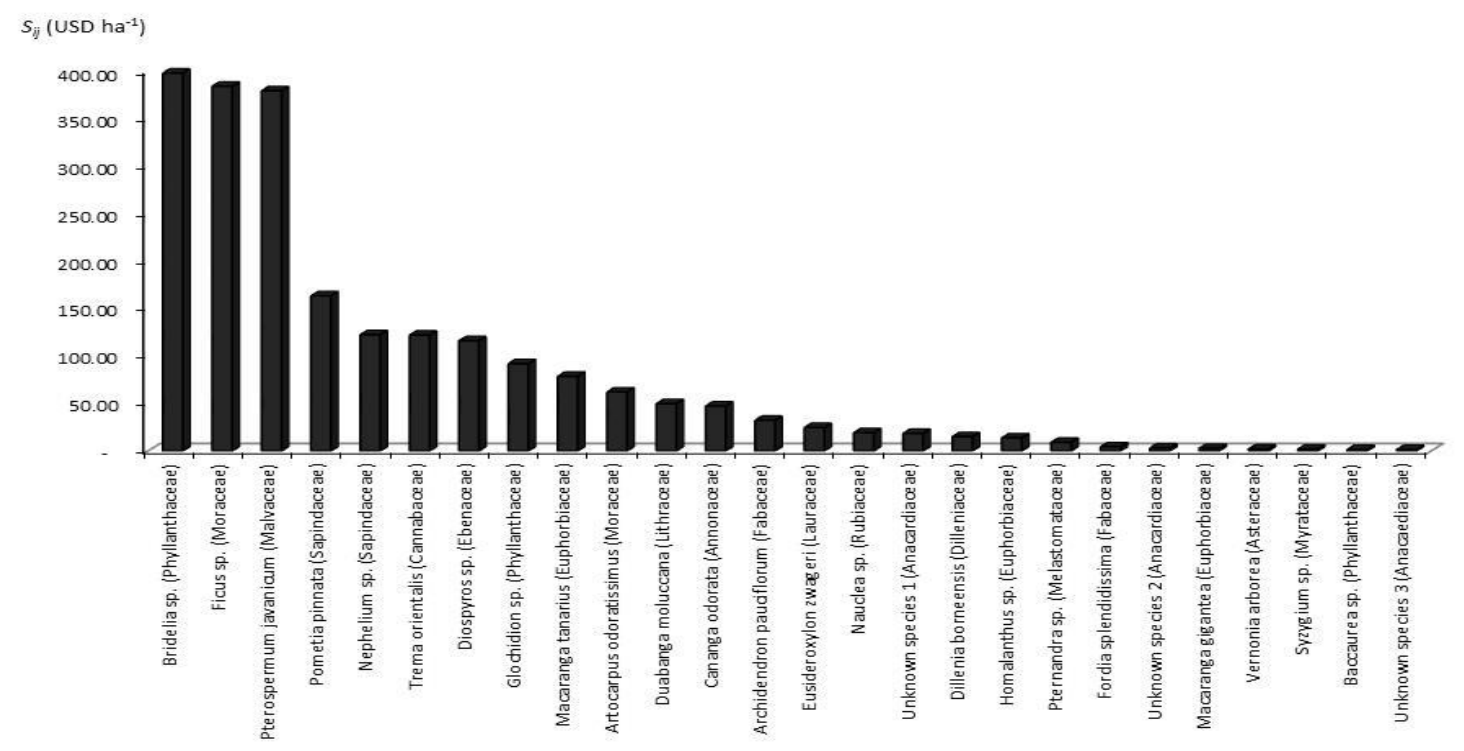

Figure 4. Stumpage values of trees at abandoned land.

\section{Conclusions}

This paper determined the abandoned lands in the tropics play important roles based on ecological and economic aspects. The ecological aspect was indicated by stand structure, floristic composition, and species diversity. The stand structure was dominated by trees with $5-10 \mathrm{~cm} \mathrm{DBH}$ class and 5-10 m height class. The average basal area and volume of the trees with DBH of $>5 \mathrm{~cm}$ were recorded $0.38 \mathrm{~m}^{2} \mathrm{ha}^{-1}$ and $3.54 \mathrm{~m}^{3} \mathrm{ha}^{-1}$. The presence of fast growing species indicated the early secondary successional process is still ongoing in the study site. The four most common species consisted mostly of light demanding pioneers, such as Macaranga tanarius, Bridelia glauca, Pterospermum javanicum, and Ficus septica in terms of IVi. The diversity indices of this abandoned land were categorized into intermediate diversity $\left(H^{\prime}\right)$, low dominance $(D s)$, and high evenness $\left(J^{\prime}\right)$. In addition, the tropical abandoned lands also have potential economic values for individuals and the community. The total of log price, logging cost, and profit margin at abandoned land were as much as $1,462.02$ USD m$^{-3} ; 1,212.24$ USD ha-1, and 337.39 USD m${ }^{-3}$, respectively. Total stumpage value of this land was estimated as much as 2,159.36 USD ha-1. Government - community cooperation need to be formulated so as to establish an appropriate method for sustainable land use. Therefore, basic information on ecological and economic aspects of abandoned lands are required for land management and conservation in the future.

\section{Acknowledgments}

The authors appreciate the Ministry of Research, Technology, and Higher Education, the Republic of Indonesia through the support provided by Hibah Penelitian Dasar Unggulan Perguruan Tinggi Contract No.: 183/SP2H/LT/DRPM/2019 for this research. 


\section{References}

Abebrese, M.O. (2002). Tropical secondary forest management in Africa. In Workshop on Tropical Secondary Forest Management in Africa: Reality and Perspectives, December 9-13, 2002 (pp. 1-7). Nairobi, Kenya.

Álvarez-Yépiz, J.C, Martínez-Yrízar, A., Búrquez, A., \& Lindquist, C. (2008). Variation in vegetation structure and soil properties related to land use history of old-growth and secondary tropical dry forests in Northwestern Mexico. Forest Ecology and Management. 256, 355-366. doi: https://doi.org/10.1016/j.foreco.2008.04.049

Brower, J.E., Zar, J.H., \& Von Ende, C.N. (1990). Field and laboratory ethods for general ecology, $3^{\text {rd }}$ Ed. USA: Wm. C. Brown Publishers.

Brown, S. \& Lugo, A.E. (1990). Tropical secondary forests. Journal of Tropical Ecology. 6, 1-32. doi: https://doi.org/10.1017/S0266467400003989

Chokkalingam, U., Smith, J., \& De Jong, W., \& Sabogal, C. (2001). A conceptual framework for the assessment of tropical secondary forest dynamics and sustainable development potential in Asia. Journal of Tropical Forest Science. 13(4), 577-600.

Danquah, J.A., Appiah, M., \& Ari, P. (2011). Comparison of post-fire planted and natural dry semideciduous forest communities in Ghana. African Journal of Agricultural Research. 6(23): 52665277. doi: https://doi.org/10.5897/AJAR11.820.

De Jong, W., Chokkalingam, U., \& Smith, J. (2001). Tropical secondary forests in Asia: Introduction and synthesis. Journal of Tropical Forest Science. 13(4), 563-576.

Fachrul, M.F. (2007). Bioecology sampling method. Jakarta: Bumi Aksara. [Indonesian]

FAO. (1996). Forest resouces assessment 1990. Survey of Tropical Forest Cover and Study of Change Processes. Italy: FAO Forestry Paper 130.

Feldpausch, T.R., Prates-Clark, C.C., Fernandes, E.C.M., \& Riha, S.J. (2007). Secondary forest growth deviation from chronosequence predictions in Central Amazonia. Global Change Biology. 13, 967-979. doi: https://doi.org/10.1111/j.1365-2486.2007.01344.x

Forestry Department of Pinansular Malaysia (FDPM). (1997). Manual kerja luar sistem pengurusan memilih. Kuala Lumpur: FDPM. [Malay]

Germain, R., Regula, J., Bick, S., \& Zhang, L. (2019). Factors impacting logging costs: A case study in the Northeast, US. The Forestry Chronicle. 95(1), 16-23. doi: https://doi.org/10.5558/tfc2019005

Hanum, F.I., Pius, P., \& Noor, A.G.A. (2001). Economic valuation of tree species diverity at Ayer Hitam Forest, Selangor, Peninsular Malaysia. Pertanika J. Trop. Agric. Sci. 22(2), 167-170.

Hikmat, A. (2005). Species composition, biomass and economic valuation of three virgin jungle reserves in Peninsular Malaysia. PhD Thesis. sBangi: Universiti Kebangsaaan Malaysia.

Husch, B., Miller, C.I., \& Beers, T.W. 1982. Forest mensuration. New York: John Wiley and Sons Publishing.

Johnson, E.A. \& Miyanishi, K. (2007). Disturbance and succession. In: Johnson, E.A., \& Miyanishi, K. (Eds.), Plant Disturbance Ecology: the Process and the Response (pp. 1-14). USA: Elsevier.

Kartawinata, K., Abdulhadi, R., \& Partomihardjo, T. (1981). Composition and structure of a lowland dipterocarp forest at Wanariset, East Kalimantan. The Malaysian Forester. 44(2 \&3): 397-406.

Karyati, Ipor, I.B., Jusoh, I., Wasli, M.E., \& Seman, I.A. (2013). Composition and diversity of plant seedlings and saplings at early secondary succession of fallow lands in Sabal, Sarawak. Acta Biologica Malaysiana. 2(3), 85-94. doi: http://dx.doi.org/10.7593/abm/2.3.85

Karyati, Ipor, I.B., Jusoh, I., \& Wasli, M.E. (2018). Tree stand floristic dynamics in secondary forests of different ages in Sarawak, Malaysia. Biodiversitas. 19(3), 687-693. doi: https://doi.org/10.13057/biodiv/d190302

Keddy, P.A. 2007. Plants and vegetation: origins, processes, consequences. New York: Cambridge University Press. 
Krebs, C.J. (2001). Ecology, $5^{\text {th }}$ Ed. USA: Addison Wesley Longman Inc.

Lanly, J.P. (1982). Tropical forest resources. FAO Forestry Paper 30. Italy: FAO.

Lawrence, D. (2004). Erosion of tree diversity during 200 years of shifting cultivation in Bornean Rain Forest. Ecological Applications. 14(6), 1855-1869. doi: https://doi.org/10.1890/03-5321

Misra, K.C. (1992). Manual of plant ecology. New Delhi: Raju Primlani.

Mittelman, A. (2001). Secondary forests in the Lower Mekong Subregion: An overview of their extent, roles and importance. Journal of Tropical Forest Science. 13(4), 671-690.

Nizam, M.S., Norziana, J., Sahibin, A.R., \& Latiff, A. (2006). Edaphic relationships among tree species in the National Park at Merapoh, Pahang, Malaysia. Jurnal Biosains. 17(2): 37-53.

Noor, A.A.G. \& Vincent, J.R., \& Yusuf, H. (1992). Comparative economic analysis of forest revenue system in Peninsular Malaysia. Osborn Center Forestry Policy Grants Program Final Report, 712.

Noor, A.A.G. \& Shahwahid, M.H.O. (1999). Price-based valuation method: stumpage appraisal of timber resources peat swamp forest. Manual on economic valuation of environmental goods and services of peat swamp forests. Kuala Lumpur: Forest Department Peninsular Malaysia.

Noor, A.A.G., Norini, H., Khamurudin, M.N., Ainuddin, A., \& Ismariah, A. (2007a). Economic valuation of timber resources in Ayer Hitam Forest Reserve, Puchong, Selangor. Pertanika J. Trop. Agric. Sci. 30(2), 83-96.

Noor, A.A.G., Norini, H., Khamurudin, M.N., Ainuddin, A., \& Ismariah, A. (2007b). Valuing the rain forest: The economic values of selected forest goods and services in Ayer Hitam Forest Reserve, Puchong, Selangor. Pertanika J. Trop. Agric. Sci. 30(2), 141-152.

Odum, P.E. (2005). Fundamentals of ecology, $5^{\text {th }}$ Ed. Belmont CA: Thomson Brooks/Cole.

Ohtsuka, T. (1999). Early stages of secondary succession on abandoned cropland in north-east Borneo island. Ecological Research. 14, 281-290. doi: https://doi.org/10.1046/j.14401703.1999.143304.x

Sapkota, I.P., Tigabu, M., \& Odén, P.C. (2010). Changes in tree species diversity and dominance across a disturbance gradient in Nepalese Sal (Shorea robusta Gaertn. f.) forests. Journal of Forestry Research. 21(1), 25-32. doi: https://doi.org/10.1007/s11676-010-0004-4

Statistics Kutai Kartanegara Regency. (2019). Kutai Kartanegara Regency in figures 2019. Retrieved from

https://kaltim.bps.go.id/pencarian.html?searching=kutai+kartanegara+dalaa+angka+2019\&yt $1=$ Cari

Tansley, A.G. (1993). An introduction to plant ecology. New Delhi: Discovery Publishing House.

Van Breugel, M., Martinez-Ramos, M., \& Bongers, F. (2006). Community dynamics during early secondary succession in Mexican tropical rain forests. Journal of Tropical Ecology. 22, 663-674. doi: $10.1017 / \mathrm{S} 0266467406003452$ 